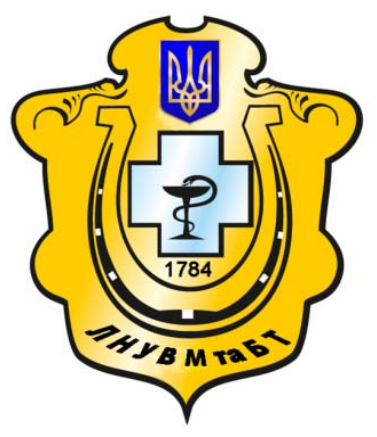

Науковий вісник Львівського національного університету ветеринарної медицини та біотехнологій імені С.3. Гжицького

Scientific Messenger of Lviv National University of Veterinary Medicine and Biotechnologies named after S.Z. Gzhytskyj

doi:10.15421/nvlvet6835

ISSN 2413-5550 print

ISSN 2518-1327 online

$\underline{\text { http://nvlvet.com.ua/ }}$

УДК 664.34:66.022.36

\title{
Вплив емульгаторів, стабілізаторів і структуроутворювачів на формування споживчих властивостей жирових продуктів
}

\author{
Б.І. Галух, М.З. Паска, У.Р. Драчук, I.М. Басараб \\ b.halukh@gmail.com, maria_pas@mail.ru,ul.drachuk@gmail.com, iryna.basarab@mail.ru \\ Львівський національний університет ветеринарної медицини та біотехнологій імені С. 3. Гжицького, \\ вул. Пекарська, 50, м. Львів, 79010, Україна;
}

\begin{abstract}
Матеріали статті відображають основні фактори створення нових жирових продуктів функціонального призначення. Проаналізовано вплив емульгаторів, стабілізаторів і структуроутворювачів на формування споживчих властивостей жирових продуктів.

Доведено, ще спільне застосування фізіологічно функціональних інгредієнтів, зокрема харчових волокон, каротиноїдів, токоферолів дозволяє отримати нові види жирових продуктів, дає можливість частково захистити їх від окиснення $i$ в сукупності забезпечити позитивний вплив на організм людини.

Обірунтовано вибір біологічно активних речовин, емульгаторів, стабілізаторів, згущувачів, які можуть бути застосовані також у технології виготовлення нових видів жирових продуктів із заданими технологічними властивостями, з метою розширення їх асортименту.

Враховуючи регіональні особливості технологій, визначено можливі напрямки промислового випуску жирових продуктів з використанням регіональних сировинних ресурсів. Встановлено необхідні кроки для вирішення поставленої проблеми розробки технологій жсирових продуктів, які мають задані властивості.

Вперше буде розроблено і впроваджено у виробничтво нові види олійно-жирових продуктів, які володітимуть високою якістю, харчовою і біологічною иінністю, тривалим терміном зберігання, і дозволить зберегти та залучити регіональні сировинні ресурси.

Ключові слова: технологія, емульгатори, стабілізатори, структуроутворювачі, емульсійні жирові продукти, біологічно активні речовини.
\end{abstract}

\section{Влияние эмульгаторов, стабилизаторов и структурообразователей на фор- мирование потребительских свойств жировых продуктов}

\author{
Б.И. Галух, М.З. Паска, У.Р. Драчук, И.М. Басараб \\ b.halukh@gmail.com, maria_pas@mail.ru, ul.drachuk@gmail.com, iryna.basarab@mail.ru
}

Львовский наџиональный университет ветеринарной медицины и биотехнологий имени С. 3. Гжицкого, ул. Пекарская, 50, г. Львов, 79010, Украина;

\footnotetext{
Материалы статьи отражают основные факторы производства жировых продуктов функционального назначения. Проанализировано влияние эмульгаторов, стабилизаторов и структурообразователей на формирование потребительских свойств жировых продуктов функиионального назначения.

Доказано, что совместное применение физиологически функииональных ингредиентов, в частности пищевых волокон, каротиноидов, токоферолов позволяет получить новые виды функииональных жировых продуктов, дает возможность частично защитить их от окисления и в совокупности обеспечить положительное влияние на организм человека.

Обоснован выбор биологически активных веществ, эмульгаторов, стабилизаторов, загустителей, которые могут быть использованы также в технологии производства новых видов жировых продуктов с заданными технологическими свойствами, с иелью расширения их ассортимента
}

\section{Citation:}

Halukh, B., Paska, M., Drachuk, U., Basarab, I. (2016). Influence of emulsifiers, stabilizers and structurantson the formation of consumer propertiesof fat-based products. Scientific Messenger LNUVMBT named after S.Z. Gzhytskyj, 18, 2(68), 165-170. 
Учитывая региональные особенности технологий, определены возможные направления промышленного выпуска жировых продуктов с использованием региональных сырьевых ресурсов. Установлены необходимые шаги для решения поставленной проблемы разработки технологий жировых продуктов, которые имеют заданные свойства.

Впервые будут разработаны и внедрены в производство новые виды масложировых продуктов, которые будут иметь высокое качество, пищевую и биологическую ченность, длительный срок хранения, и позволит сохранить и привлечь региональные сырьевые ресурсы.

Ключевые слова: технология, эмульгаторы, стабилизаторы, структурообразователи, эмульсионные жировые продукты, биологически активные вешества.

\title{
Influence of emulsifiers, stabilizers and structurantson the formation of consumer propertiesof fat-based products
}

\author{
B. Halukh, M. Paska, U. Drachuk, I. Basarab \\ b.halukh@gmail.com, maria_pas@mail.ru, ul.drachuk@gmail.com, iryna.basarab@mail.ru \\ ${ }^{1}$ Lviv national university of veterinary medicine and biotechnologies named after S. Gzhytskyj, \\ Pekarska Str., 50, Lviv, 79010, Ukraine;
}

Materials of article reflects the main factors of making fat products with functional purposes. It has been analyzed influence of emulsifiers, stabilizers and structure-formation on consumer properties of fatty foods.

Proved that the combined use of physiologically functional ingredients, including dietary fiber, carotenoids, tocopherols allows to get new types of functional fatty foods, allows partially protect them from oxidation and in aggregate provide a positive impact on the human body.

Proved the selection of biologically active substances, emulsifiers, stabilizers, thickeners which can be used also in the manufacturing technology of new kinds of fat products with desired technological properties, in order to expand their range.

Taking into account regional features, identified possible directions for industrial production of fat products with the use of regional raw materials. Has established the necessary steps to solve the problems of the development of functional fatty products technologies that have functional properties.

For the first time will be developed and introduced into the production new types of oil and fat products, that will have high quality, nutritional and biological value, long shelf life and will allow preserving and attract regional raw materials.

Key words: technology, emulsifiers, stabilizers, structure-, fat emulsion products, biologically active substances, the products functionality.

\section{Встуі}

Соуси - полікомпонентна система, а якісний і кількісний склад інгредієнтів визначає їх функції і властивості. Окрім рослинної олії і води до складу соусів, входять емульгатори, стабілізатори, структуроутворювачі, а також смакові, функціональні та інші харчові добавки, які надають майонезу різноманітних смаків, аромату, формують харчову і біологічну і фізіологічну цінність, що, в сою чергу, дозволяє створити великий асортимент цих продуктів (Nechaev et al., 2000).

Емульсії за своєю природою є термодинамічно нестабільними структурами. Головні причини, які викликають їх нестійкість - це розшарування, флокуляція, коалесценція, i, рідше, порушення пропорційності та конвективна нестійкість. Саме тому для надання емульсіям стійкості використовують емульгатори речовини, що мають дифільну будову молекули i здатні частково розчинятися як в олії, так і у воді, зв'язуючи ці компоненти один з одним (Fridrihsberg, 1984; Golubev and Chicheva, 2003; Kovalevskij, 2005; Muhamediev and Vas'kina, 2008).

У промислових умовах для отримання емульсій типу «олія у воді» використовують гідрофільні емульгатори, які краще розчиняються у воді, аніж у олії. Емульгатори адсорбуються на межі розділу фаз і знижують міжфазний поверхневий натяг, сприяючи, таким чином, диспергуванню (Fridrihsberg, 1984; Paronjan and Bogoljubskaja, 2007).

Технологічними основами для створення продуктів спеціалізованого і функціонального призначення $є$ жирові продукти емульсійного типу (Burkitt et al., 1972; Gibson and Williams, 2000; Shi, 2007).

Метою роботи було дослідити вплив емульгаторів, стабілізаторів і структуроутворювачів на формування споживчих властивостей жирових продуктів.

\section{Результати та їх обговорення}

Емульгатори класифікують за електрохімічним зарядом у водних системах, відношенням до розчинників, функціональними групами, співвідношенням гідрофільних і ліпофільних груп (гідрофільноліпофільний баланс ГЛБ) (Kovalevskij, 2005).

На сучасному етапі розвитку харчова промисловість має в своєму розпорядженні широкий вибір емульгаторів, які, за природою їх походження, а також особливостям складу і будови, можна (умовно) поділити на наступні основні види:

- природні емульгатори на основі протеїнів рослинного походження (білкові соєві ізоляти);

- природні емульгатори на основі протеїнів тваринного походження (молочні білки і сироваткові молочні концентрати);

- моно-і дигліцериди харчових жирних кислот;

- рослинні і тваринні фосфоліпіди; 
- штучні емульгатори (поліфосфати і синтетичні фосфоліпіди, наприклад, емульгатор ФОЛС).

Слід вказати, що залежно від хімічної природи емульгатора, а також специфіки харчової системи, до якої він вводиться, деякі $з$ представників цього функціонального класу харчових добавок можуть виконувати суміжні технологічні функції (функції стабілізаторів і антиоксидантів). 3 цих причинах харчові добавки інших класів можуть проявляти в харчових системах емульгуючу здатність (Paronjan and Bogoljubskaja, 2007).

Вартий уваги той факт, що серед низькомолекулярних сполук основними поверхнево-активними речовинами, які здатні виконувати роль стабілізаторів, є фосфоліпіди. Вони мають дифільну структуру: в ліпофільній частині якої знаходяться два жирнокислотні радикали, а в гідрофільній - залишок фосфорної кислоти. В дисперсних системах фосфоліпіди виконують різні технологічні функції: емульгатора, стабілізатора, антиоксиданту, консерванту, біологічно активної речовини. Продуктом переробки рослинних олій $є$ фосфоліпідні концентрати (лецитини) (Tereshhuk et al., 2015). Харчову добавку Е 322 лецитин використовують в багатьох галузях харчової промисловості - олійно-жировій, м'ясопереробній, кондитерській, хлібопекарській, а також при виробництві дитячого харчування. Промисловість розвинених країн випускає лецитин у вигляді порошків, гранул і рідких препаратів, в яких зміст фосфоліпідів перевищує 97\%. Він добре розчиняється в оліях і жирах.

Слід зазначити, що лецитини також використовують як антиоксидант, який перешкоджає окисненню жирових продуктів: маргаринів, майонезів. Лецитини здатні утворювати стійкі комплекси з металами. Оскільки майже у всіх видах виробництв, при технологічній обробці олія контактує 3 металевими поверхнями технологічного обладнання (Sarkisjan et al., 2013).

Відомо, що фосфоліпіди i, перш за все, фосфатидилхоліни, володіють гіполіпідемічними властивостями. Ці властивості проявляються за рахунок їх здатності знижувати рівень холестеролу і ліпідів у сироватці крові, зниження інтенсивності синтезу холестеролу i його ефірів гепатоцитами, а також, шляхом нормалізації структури ліпопротеїнів низької щільності. Крім того, на клітинному рівні, фосфоліпіди сприяють нормалізації роботи клітинних мембран i функціональної активності рецепторів. Це забезпечує поліпшення взаємодії ліпопротеїдів з ферментами і нормалізацію катаболізму ліпопротеїдів на клітинному рівні (Butina et al., 2005; Greco and Bruno, 2008; Vaclavik and Christian, 2008).

У роботі Жане М.Р. досліджено вміст фізіологічно функціональних інгредієнтів соєвого лецитину: фосфоліпідів 62 г/100г, фосфатидилхоліну - 25 г/100г, фосфатидилетаноламіну - 14 г/100г, фосфатидилінозитолу - 8 г/100г, фосфатидилсерину - 7,5 г/100г, дифосфатидилгліцерину - 3 г/100г, поліненасичених жирних кислот - 49,3 г/100г, вітаміну E - 78,15 г/100г, провітаміну D ( $\beta$-ситостеролу) - 390,0 мг/100г, вітаміну В4 (холін) 2270 г/100г, макроелементів: $\mathrm{Ca}, \mathrm{Mg}$, K, Р, мікроелементів - Fe, $\mathrm{Cu}$ (Zhane et al., 2013).
Таким чином, емульгатори полегшують первинне диспергування і надають емульсіям стійкості. Проте проблему тривалої стійкості емульсій емульгатори не вирішують. Деемульгуванню емульсій сприяють процеси, розшарування, флокуляції, коалесценції, порушення пропорційності тощо (Muhamediev and Vas'kina, 2008).

Показовим є те, що, стійкі емульсії низької жирності можна отримати використовуючи стабілізатори, додавання яких сприяє підвищенню стійкості емульсій за рахунок підвищення в'язкості безперервної фази і завдяки їх захисній дії. Вказаними якостями володіють високомолекулярні речовини - гідроколоїди.

Із проаналізованих даних слід відмітити, що, маючи довголанцюгову структуру, стабілізатори обволікають частинки дисперсної фази. Не проникаючи, як емульгатори, всередину структури, вони підсилюють електричні заряди (укріплюють сольватні оболонки) i, таким чином, підвищують стійкість системи. Макромолекулярні гідрофільні стабілізатори, в якості яких найчастіше використовують гідроколоїди, утворюють в'язкі розчини, перешкоджаючи виникненню процесу седиментації.

Експериментально встановлено, що для стабілізації низькожирних емульсій ефективнішим є використання структуроутворювачів, які створюють на межі розділу двох фаз розгалужені адсорбційні шари, які здатні до специфічної взаємодії між собою на межі контакту частинок дисперсної фази, утворюючи міцні водневі, іонно-електростатичні і гідрофобні зв'язки (Skrjabina et al., 2007; Vorob'eva and Volkova, 2008; Paska, 2015).

Отож, для створення в'язкої стійкої гелеподібної структури низько- і средньокалорійних майонезів із підвищеним вмістом води в рецептури додають згущувачі-структуроутворювачі. При їх використанні дисперсне середовище емульсії перетворюється на гель, додатково перешкоджаючи розшаруванню емульсій 3 відносно невеликим вмістом жирової фази, дані цього дослідження описано в роботі Федорової Н.Б. (Fedorova, 2005; Galuh et al., 2014).

При створенні жирових продуктів із заданими властвостями разом 3 рішенням технологічної задачі отримання стійкої емульсії необхідно забезпечити високу біологічну цінність продукту, яка визначатиметься фізіологічною і харчовою цінністю рецептурних компонентів. Вочевидь, при виборі нетрадиційних емульгаторів, в першу чергу, необхідно керуватися їх нешкідливістю і фізіологічною цінністю для організму. 3 цих позицій безумовна перевага може бути віддана природнім емульгаторам як рослинного так і тваринного походження (Parshakova et al., 2006; Paska et al., 2013; Makeeva et al., 2016).

Натуральні гідроколоїдні стабілізатори можуть бути класифіковані залежно від морфологічної приналежності:

- білкової природи - желатин, казеїнати, альбумін;

- рослин - гуміарабік, камедь (карайя і трагакантова камедь);

- камедь насіння - гуарова, кароб (ріжкове дерево), псиліум; 
- крохмал і модифіковані крохмалі;

- камедь мікробного походження - ксантан;

- екстракти водоростей - агар, альгінати, карагінан;

- пектини - низькомолекулярний і високомолекулярний метоксил;

- поліфруктозани - інулін;

- целюлоза - карбоксиметилцелюлоза натрію, мітив і метилэтил целюлозу, гідроксипропілцелюлоза і гідроксипропілметилцелюлоза.

За походженням гідроколоїди поділяють на дві групи: природного і синтетичного (напівсинтетичного) походження (Parshakova et al., 2006; Voskanjan et al., 2016). Ці речовини відіграють важливу роль у функціонуванні органів і систем організму, в першу чергу, органів травної системи. Вони адсорбують значну кількість жовчних кислот, а також інші метаболіти, токсини, і електроліти, сприяючи детоксикації організму.

Було також встановлено, що багато натуральних харчових стабілізаторів за структурою і властивостями $\epsilon$ гідроколоїдами. Вони складаються 3 дуже великих і об'ємних полімерних макромолекул і володіють значною спорідненістю до води, внаслідок чого відбувається їх гідратація і набухання (Parshakova et al., 2006).

Технологічні і функціональні характеристики стабілізуючих добавок

\begin{tabular}{|c|c|c|c|c|}
\hline Найменування добавки & $\begin{array}{c}\text { Розчинність у воді при } \\
\text { температурі, }{ }^{\circ} \mathrm{C}\end{array}$ & $\begin{array}{l}\text { Опти-мальні } \\
\text { рН середовища }\end{array}$ & Застосу-вання & $\begin{array}{c}\text { Вплив на організм } \\
\text { людини }\end{array}$ \\
\hline 1 & 2 & 3 & 4 & 5 \\
\hline Желатин & 60 & $4,5-10,0$ & Гелеутво-рювач & $\begin{array}{l}\text { Побічні ефекти } \\
\text { невідомі }\end{array}$ \\
\hline $\begin{array}{l}\text { Модіфіковані молочні } \\
\text { білки }\end{array}$ & $70 \pm 5$ & $6,2-6,9$ & Загущувач & $\begin{array}{l}\text { Побічні ефекти } \\
\text { невідомі }\end{array}$ \\
\hline $\begin{array}{c}\text { Модіфіковані соєві } \\
\text { білки }\end{array}$ & $20-40$ & $6,8-7,3$ & Загущувач & $\begin{array}{c}\text { Побічні ефекти } \\
\text { невідомі }\end{array}$ \\
\hline Гуміарабік & $20 \pm 2$ & & Загущувач & $\begin{array}{c}\text { Побічні ефекти } \\
\text { невідомі }\end{array}$ \\
\hline Гумікарайя & 20 & & Загущувач & $\begin{array}{c}\text { Побічні ефекти } \\
\text { невідомі }\end{array}$ \\
\hline Трагакант камедь & 20 & & Загущувач & Можливі алергічні реакції \\
\hline Гумігаті & 20 & & Загущувач & $\begin{array}{l}\text { Побічні ефекти } \\
\text { невідомі }\end{array}$ \\
\hline Гуарова камедь & 20 & & Загущувач & Знижує рівень холестеролу \\
\hline $\begin{array}{c}\text { Камедь ріжкового } \\
\text { дерева }\end{array}$ & 70 & & Загущувач & Знижує рівень холестеролу \\
\hline $\begin{array}{l}\text { Камедь насіння } \\
\text { айви }\end{array}$ & 20 & & Загущувач & $\begin{array}{c}\text { Побічні ефекти } \\
\text { невідомі }\end{array}$ \\
\hline $\begin{array}{c}\text { Ксантова } \\
\text { камедь }\end{array}$ & 20 & $2,0-12,0$ & Загущувач & $\begin{array}{c}\text { Побічні ефекти } \\
\text { невідомі }\end{array}$ \\
\hline $\begin{array}{c}\text { Альгінова } \\
\text { кислота, } \\
\text { альгінат натрію, } \\
\text { альгінат калію, } \\
\text { альгінат амонію, } \\
\text { альгінат кальцію } \\
\end{array}$ & 20 & $2,8-10,0$ & Загущувач & $\begin{array}{c}\text { Детоксикаційні і радіопроте- } \\
\text { кторні властивості, нормалі- } \\
\text { зує функцію кишечника, } \\
\text { здатний зв’язувати іони важ- } \\
\text { ких металів }\end{array}$ \\
\hline Агар- агар & $40-50$ & $4,5-10,0$ & Гелеутворювач & $\begin{array}{c}\text { У дозі більше 5г діє як про- } \\
\text { носне }\end{array}$ \\
\hline $\begin{array}{l}\text { Карагінан і його натріє- } \\
\text { ва (калієва), амонійна } \\
\text { солі }\end{array}$ & $50-60$ & $4,0-10,0$ & Гелеутворювач & $\begin{array}{l}\text { Побічні ефекти } \\
\text { невідомі }\end{array}$ \\
\hline Інулін & 20 & $4,0-9,0$ & Гелеутворювач & Знижує рівень холестеролу \\
\hline $\begin{array}{c}\text { Карбоксиме- } \\
\text { тилцелюлоза (КМЦ) }\end{array}$ & $8-50$ & $5,0-9,0$ & $\begin{array}{c}\text { Загущувач, } \\
\text { стабіліза-тор }\end{array}$ & $\begin{array}{l}\text { Побічні ефекти } \\
\text { невідомі }\end{array}$ \\
\hline Модифіковані крохмалі & $80-90$ & $8,0-12,0$ & Гелеутворювач & $\begin{array}{l}\text { Побічні ефекти } \\
\text { невідомі }\end{array}$ \\
\hline Метилцелю-лоза & $8-10$ & $2,0-13,0$ & $\begin{array}{l}\text { Загущувач, ста- } \\
\text { біліза-тор } \\
\end{array}$ & $\begin{array}{c}\text { Побічні ефекти } \\
\text { невідомі }\end{array}$ \\
\hline $\begin{array}{c}\text { Пектин високоетерифі- } \\
\text { кований }\end{array}$ & 20 & $2,5-4,0$ & Стабіліза-тор & $\begin{array}{c}\text { Детоксикаційні і радіопро- } \\
\text { текторні властивості, здатний } \\
\text { зв'язувати іони важких ме- } \\
\text { талів. Високі дози можуть } \\
\text { викликати дискомфорт в } \\
\text { кишечнику. }\end{array}$ \\
\hline
\end{tabular}


Інулін - натуральний полісахарид, який отримують 3 кореня цикорію і бульб топінамбура. Покращує роботу травної системи, забезпечуює зростання власної біфідофлори кишечника, сприяючи підвищенню імунітету, поліпшенню засвоєння кальцію, зниженню рівня холестерину в крові і індексу маси тіла і навіть зменшують ризик раки кишечника. Інулін володіє низькою розчинністю у воді, i, внаслідок цього, здатністю утворювати з водою жироподібний гель. Інулін має калорійність 1 ккал/1г, що істотно нижче за калорійність жиру. Він здатний «імітувати» присутність жиру в продукті з пониженою жирністю, наближаючи характеристики продукт до продукту з нормальною жирністю (Burkitt et al., 1972; Rimm et al., 1996; Utesheva and Nechaev, 2007; Galuh et al., 2014).

Слід зауважити, що несення до складу рецептур майонезів і соусів зниженої жирності інуліну є перспективним $з$ технологічної точки зору. Харчові волокна, які входять до складу інуліну володіють властивістю органолептично імітувати жирову складову в рецептурах, позитивно впливають на текстуру продукту, мають м'який нейтральний смак і легко поєднуються 3 рецептурними компонентами, дозволяючи розробити рецептури нових жирових продуктів без особливих змін смаку (Eliseeva, 2008; Perkovec and Shuvaeva, 2012; Paska et al., 2013; Voskanjan et al., 2016).

Виходячи 3 отриманих даних, інулін здатний знижувати жирність жирових продуктів без погіршення їх споживчих якостей, надаючи їм прогнозованих властивостей. Таким чином, жирові продукти які містять інулін націлені на зменшення ризиків виникнення ожиріння і серцево-судинних захворювань людини (Perkovec and Shuvaeva, 2012; Martirosjan et al., 2012; Salenko and Makina, 2013; Paska et al., 2014).

Функціонально-технологічні характеристики стабілізуючих добавок наведено в таблиці (Golubev and Sheluhina, 1995; Zajko, 1997; Sarafanova, 1999; Nechaev et al., 2000; Nechaev et al., 2002; Bazarnova et al., 2005; Kozhuhova et al., 2005; Panfilova, 2006; Uajthauz, 2008).

Перспективи подальших досліджень. Подальші дослідження будуть скеровані на вивчення способів одержання функціональних інгредієнтів із сировини Карпатського регіону для включення до складу рецептур олійно-жирових продуктів.

\section{Висновки}

1. Теоретично обгрунтовано співвідношення (інгредієнтів рецептури) емульсії та зміни ії характеристик за допомогою стабілізаторів, емульгаторів і функціональних інгредієнтів.

2. Доведено можливість варіювання рецептур жирових продуктів емульсійної природи із заданими функціональними властивостями і різною консистенцією з метою створення нових видів жирових продуктів, які володітимуть високою якістю, харчовою i біологічною цінністю, тривалим терміном зберігання, і дозволить зберегти та залучити регіональні сировинні ресурси.

\section{Бібліографічні посилання}

Nechaev, A.P., Kochetkova, A.A., Nesterov, I.N. (2000). Majonezy. SPb: GIORD (in Russian).

Fridrihsberg, D.A. (1984). Kurs kolloidnoj himii. L.: Himija (in Russian).

Golubev, V.N., Chicheva, L.V. (2003). Pishhevye i biologicheski aktivnye dobavki. M: Akademija (in Russian).

Muhamediev, Sh.A., Vas'kina, V.A. (2008). Jemul'sii i peny: stroenie, poluchenie, ustojchivost'. Masla i zhiry. 9,11, 2-5 (in Russian).

Kovalevskij, A.A. (2005). Razrabotka receptur potrebitel'skih svojstv saharnogo pechen'ja, obogashhennogo fosfolipidnym produktom «holin» $\mathrm{i}$ tomatno-masljanym jekstraktom: dis. kand. teh. nauk: 05.18.15. Krasnodar.

Paronjan, V.H., Bogoljubskaja, Ju.V. (2007). Teoreticheskie osnovy obrazovanija jemul'sij i kriterii ocenki ih svojstv. Hranenie i pererabotka sel'hozsyr'ja. 4, 20-22 (in Russian).

Sarkisjan, V.A., Smirnova, E.A., Kochetkova, A.A., Bessonov, V.V. (2013). Sinergicheskie vzaimodejstvija antioksidantov v zhirovyh produktah. Pishhevaja promyshlennost'. 3, 14-17 (in Russian).

Butina, E.A., Gerasimenko, E.O., Pribytko, A.P., Abaeva, I.N. (2005). Sravnitel'nye issledovanija parafarmacevticheskih svojstv fosfolipidnyh BAD serii Vitol. Uspehi sovremennogo estestvoznanija. 8, 66-67 (in Russian).

Zhane, M.R., Lisovaja, E.V., Kornena, E.P. (2013). Primenenie fosfolipidnyh i vitaminno-mineral'nopolisaharidnoj dobavok $\mathrm{v}$ proizvodstve majoneznyh sousov [Jelektronnyj resurs]. Elektron. dan. Krasnodar, $\quad-\quad$ [2013]. dostupa: http://www.vniitti.ru/conf/conf2013/proizv-hran.php (in Russian).

Skrjabina, N.M., Bogoljubskaja, Ju.V., Paronjan, V.H. (2007). Issledovanie mehanizma jemul'girovanija pishhevyh produktov / N.M. Skrjabina, // Hranenie i pererabotka sel'hozsyr'ja. 4, S.22-23 (in Russian).

Fedorova, N.B. (2005). Razrabotka receptur i ocenka potrebitel'skih svojstv nizkokalorijnyh majonezov funkcional'nogo naznachenija $\mathrm{s}$ primeneniem fosfolipidnyh i belkovyh dobavok: dis. kand. teh. nauk: 05.18.06, 05.18.15. Krasnodar (in Russian).

Parshakova, L.P., Demchenko, L.A., Draganova, E.I. (2006). Novye stabilizacionnye sistemy dlja majoneznyh jemul'sij / L.P. Parshakova, // Maslozhirovaja promyshlennost'. 6, 28-29 (in Russian).

Eliseeva, N.E. (2008). Nizkozhirnye majonezy i sousy s pishhevymi voloknami i kompleksom biologicheski aktivnyh soedinenij. Maslozhirovaja promyshlennost'. 4, 40-44 (in Russian).

Perkovec, M.V., Shuvaeva, A.N. (2012). Inulin i oligofruktoza funkcional'nye ingredienty dlja maslozhirovoj promyshlennosti. Maslozhirovaja promyshlennost'. 5, 29-30 (in Russian).

Salenko, R.N., Makina, V.D. (2013). Issledovanie profilakticheskih svojstv jekstruzicionnyh produktov, 
obogashhennyh inulinom. Pishhevaja promyshlennost'. 3, 24-26 (in Russian).

Martirosjan, V.V., Sapenko, R.N., Zhirokova, E.V., Malkina, V.D. (2012). Obogashhenie jekstruzionnyh produktov inulinom. Pishhevaja promyshlennost'. 9, 42-44 (in Russian).

Golubev, V.N., Sheluhina, N.P. (1995). Pektin: himija, tehnologija, primenenie. M.: ATN RF (in Russian).

Bazarnova, Ju.G., Shkotova, T.V., Zjukanov, V.M. (2005). Primenenie natural'nyh gidrokolloidov dlja stabilizacii pishhevyh produktov. Pishhevye ingredienty. Syr'e i dobavki. 2, 84-87 (in Russian).

Panfilova, M.N. (2006). Ksantovaja kamed'. Primenenie v maslozhirovom proizvodstve. Pishhevaja promyshlennost'. 11, 18 (in Russian).

Nechaev, A.P., Kochetkova, A.A., Zajcev, A.N. (2002). Pishhevye dobavki. M: Kolos. Kolos-Press (in Russian).

Kozhuhova, A.A., Chernega, I.V., Barhatova, T.V., Petrichenko, L.K. (2005). Sravnitel'naja harakteristika stukruroobrazovatelej uglevodnoj prirody. Pishhevye ingredienty. Syr'e i dobavki. 2, 88-89 (in Russian).

Sarafanova, L.A. (1999). Primenenie pishhevyh dobavok. Tehnicheskie rekomendacii. 3-e izd. pererab. i dop. SPb.: GIORD (in Russian).

Zajko, G.M. (1997). Poluchenie i primenenie pektina dlja lechebnyh i profilakticheskih celej. Krasnodar: KubGTU (in Russian).

Uajthauz, F.K. (2008). Vybor i ispol'zovanie gidrokolloidov. Pishhevaja promyshlennost'. 10, 7678 (in Russian).

Makeeva, I.A., Prjanichnikova, N.S., Bogatyrev, A.N. (2016). Nauchnye podhody k vyboru netradicionnyh ingredientov dlja sozdanija funkcional'nyh produktov zhivotnogo proishozhdenija, $\mathrm{v}$ tom chisle organicheskih. Pishhevaja promyshlennost'. 3, 34-37 (in Russian).

Voskanjan, O.S., Nikitin, I.A., Guseva, D.A. (2016). Razrabotka i issledovanie zhirovoj osnovy jemul'sionnyh produktov pitanija funkcional'nogo naznachenija $\mathrm{s}$ primeneniem tradicionnyh i netradicionnyh ingredientov. Pishhevaja promyshlennost'. 3, 10-15 (in Russian).

Tereshhuk, L.V., Starovojtova, K.V., Dolgoljuk, I.V. Tarljun, M.A. (2015). Rastitel'nye masla v kachestve funkcional'nyh ingredientov jemul'sionnyh produktov. Maslozhirovaja promyshlennost'. 2, 20-23 (in Russian).
Greco, L.V., Bruno, M.N. (2008). Food science and technology : new research. New York: Nova Science Publishers.

Vaclavik, V., Christian, E.W. (2008). Essentials of food science, $3^{\text {rd }}$ ed. New York, NY: Springer.

Smith, J., Charter, E. (2010). Functional food product development. Inc., USA

Gibson, G.R., Williams, C.M. (2000). Functional foods: concept to product. Woodhead Publishing Limited, Cambridge, England.

Shi, J. (2007). Functional food ingredients and nutraceuticals: processing and technologies. Boca Raton, FL: CRC/Taylor \& Francis.

Burkitt, D.P., Walker, A.R., Painter, N.S. (1972). Effect of dietary fiber on stods and transittimes and its role in the caubbation of diseasae. Lancet. 2, 14081412.

Vorob'eva, A.V., Volkova, N.N. (2008). Sovremennye tendencii sozdanija jemul'sionnyh produktov dlja zdorovogo pitanija. Pishhevaja promyshlennost'. 11, 72 (in Russian).

Rimm, E.B., Ascherio, A., Giovannucci, E., Spiegelman, D., Stampfer, M.J., Willett, W.C. (1996). Vegetable, fruit, and cereal fiber intake and risk of coronary heart disease among men. JAMA. 14, 275(6), 447-451.

Utesheva, S.Ju., Nechaev, A.P. (2007). Tendencii v sozdanii majonezov i sousov funkcional'nogo naznachenija. Maslozhirovaja promyshlennost'. 3, 1216 (in Russian).

Galuh, B.I., Paska, M.Z., Drachuk, U.R. (2014). Doslidzhennja stijkosti majoneznyh emul'sij vygotovlenyh iz vykorystannjam harchovyh volokon. Naukovyj visnyk LNUVMBT imeni S.Z.G'zhyc'kogo. 16, 3(60), 21-30 (in Ukrainian).

Paska, M.Z., Zhuk, O.I, Martynjuk, I.O, Drachuk, U.R (2013). Inovacijni tehnologii' u olijno-zhyrovij promyslovosti. Naukovyj visnyk LNUVMBT im. S.Z. Gzhyc'kogo. 3(57), 102-116 (in Ukrainian).

Paska, M.Z. Zhuk, O.I., Galuh, B.I., Drachuk, U.R. (2014). Energozberezhennja v suchasnyh umovah na pidpryjemstvah olijno-zhyrovoi' promyslovosti. Naukovyj vis- nyk LNUVMBT im. S. Z. G'zhyc'kogo. L'viv. 16, 3(60), 129-136 (in Ukrainian).

Paska, M.Z. (2015). Vykorystannja innovacijnogo obladnannja Fryma Koruma MaxxD, u vyrobnyctvi majonezu. Shidno-Jevropejs'kyj zhurnal peredovyh tehnologij. Harkiv, 2/ 10 (74) (in Ukrainian).

Стаття надійшла до редакиї 6.10.2016 